University of Nebraska - Lincoln DigitalCommons@University of Nebraska - Lincoln

2013

\title{
Sedentism, Social Change, Warfare, and the Bow in the Ancient Pueblo Southwest
}

\author{
Paul F. Reed \\ ArchaeologySouthwest, preed@archaeologysouthwest.org \\ Phil R. Geib \\ University of Nebraska - Lincoln, pgeib2@unl.edu
}

Follow this and additional works at: http://digitalcommons.unl.edu/anthropologyfacpub

Part of the Archaeological Anthropology Commons, and the Social and Cultural Anthropology Commons

Reed, Paul F. and Geib, Phil R., "Sedentism, Social Change, Warfare, and the Bow in the Ancient Pueblo Southwest" (2013).

Anthropology Faculty Publications. 148.

http://digitalcommons.unl.edu/anthropologyfacpub/148

This Article is brought to you for free and open access by the Anthropology, Department of at DigitalCommons@University of Nebraska - Lincoln. It has been accepted for inclusion in Anthropology Faculty Publications by an authorized administrator of DigitalCommons@University of Nebraska Lincoln. 


\title{
Sedentism, Social Change, Warfare, and the Bow in the Ancient Pueblo Southwest
}

\author{
Paul F. Reed and Phil R. Geib
}

\begin{abstract}
In the ancient American Southwest, use of the bow developed relatively rapidly among Pueblo people by the fifth century AD. This new technology replaced the millennia-old atlatl and dart weaponry system. Roughly 150 years later in the AD 600s, Pueblo socioeconomic organization began to evolve rapidly, as many groups adopted a much more sedentary life. Multiple factors converged to allow this sedentary pattern to emerge, but the role of the bow in this process has not been fully explored. In this paper, we trace the development of the bow and discuss its role as sedentism emerged and social changes occurred in ancient Puebloan society from the fifth through seventh centuries AD.
\end{abstract}

Keywords: bow, Basketmakers, Ancestral Pueblo, maize

$\mathrm{T}^{\mathrm{s}}$ he development and spread of bow technology across North America has spawned considerable archeological debate for more than 100 years. ${ }^{1-7}$ Various schemes have been proposed for the spread of bow technology from Asia between 4000 and 2000 BP. Despite the debate over the exact timing, bow technology was present across the North American continent by AD 400-800. In the ancient American Southwest, the earliest indications of bow use occur in the AD 100-400 interval. ${ }^{8}$ In this paper, we focus on the timing of the adoption of bow technology in the northern Puebloan Southwest and its relationship to sedentism, warfare, and social complexity. We also discuss various locales with early bow use in the northern Southwest (Fig. 1). We evaluate the evidence with regard to the social coercion and warfare theories discussed by Bingham and his colleagues in this issue. 9,10 $^{-10}$

\section{A Brief Sketch of Early Puebloan History}

To assess how the introduction of bow technology to the Southwest potentially affected cultural developments in the region, we need to briefly outline early Pueblo cultural history, with particular attention to the roughly 500-year interval during the first millennium AD. The original framework for discussing Puebloan history in the Southwest is designated as the Pecos Classification. It was intended as a developmental rather than chronological framework and assumed a progression from the distant past to ethnographic Puebloan groups. ${ }^{11}$ The sequence consists of three Basketmaker periods (IIII) at the early end and five Puebloan stages (I-V). Basketmaker I was later abandoned, as it corresponded to late Archaic, pre-Puebloan developments. The Pecos framework is still commonly used, although the notion of "progressive" development has been dropped and replaced by simple chronological intervals. In the many decades since its formulation, archeologists have fleshed out the details of cultural change throughout most of the Southwest, There currently exist a plethora of regional sequences and phase names.

Central to cultural developments throughout the entire Southwest is the use of cultigens, particularly maize. Whether adopted in situ by foragers or introduced by migrant farmer-foragers, ${ }^{12}$ maize was present in the Southwest by about 2100 BC. ${ }^{13}$ Maize, or the use of domesticates more generally, was a critical defining characteristic of the Basketmaker II period as originally conceived, which was designated as the prepottery, atlatl-using, initial farming stage (Fig. 2). This interval is very lengthy (ca. 2100 BC$\mathrm{AD} 400$ ) and the earliest portion of it, before $400 \mathrm{BC}$, is still poorly known. Nonetheless, by at least $400 \mathrm{BC}$ and perhaps hundreds of years earlier, there is good evidence that Basketmaker groups in various areas were largely dependent on maize agriculture. ${ }^{14-18}$

Paul F. Reed is a Preservation Archaeologist with Archaeology Southwest (formerly the Center for Desert Archaeology) currently assigned as Chaco Scholar at Salmon Ruins Museum, New Mexico. Reed's research interests include ancient Puebloan community organization and social development and Chacoan economic and ritual organization. Email: preed@archaeologysouthwest.org

Phil Geib has worked as an archaeologist for 30 years, mostly on the Colorado Plateau in Utah and Arizona. His main research concerns preceramic foragers and farmers and various prehistoric technologies. Geib's dissertation research concerns conflict and warfare during the interval when domesticates were initially used in the North American Southwest. Email: pgeib@unm.edu 


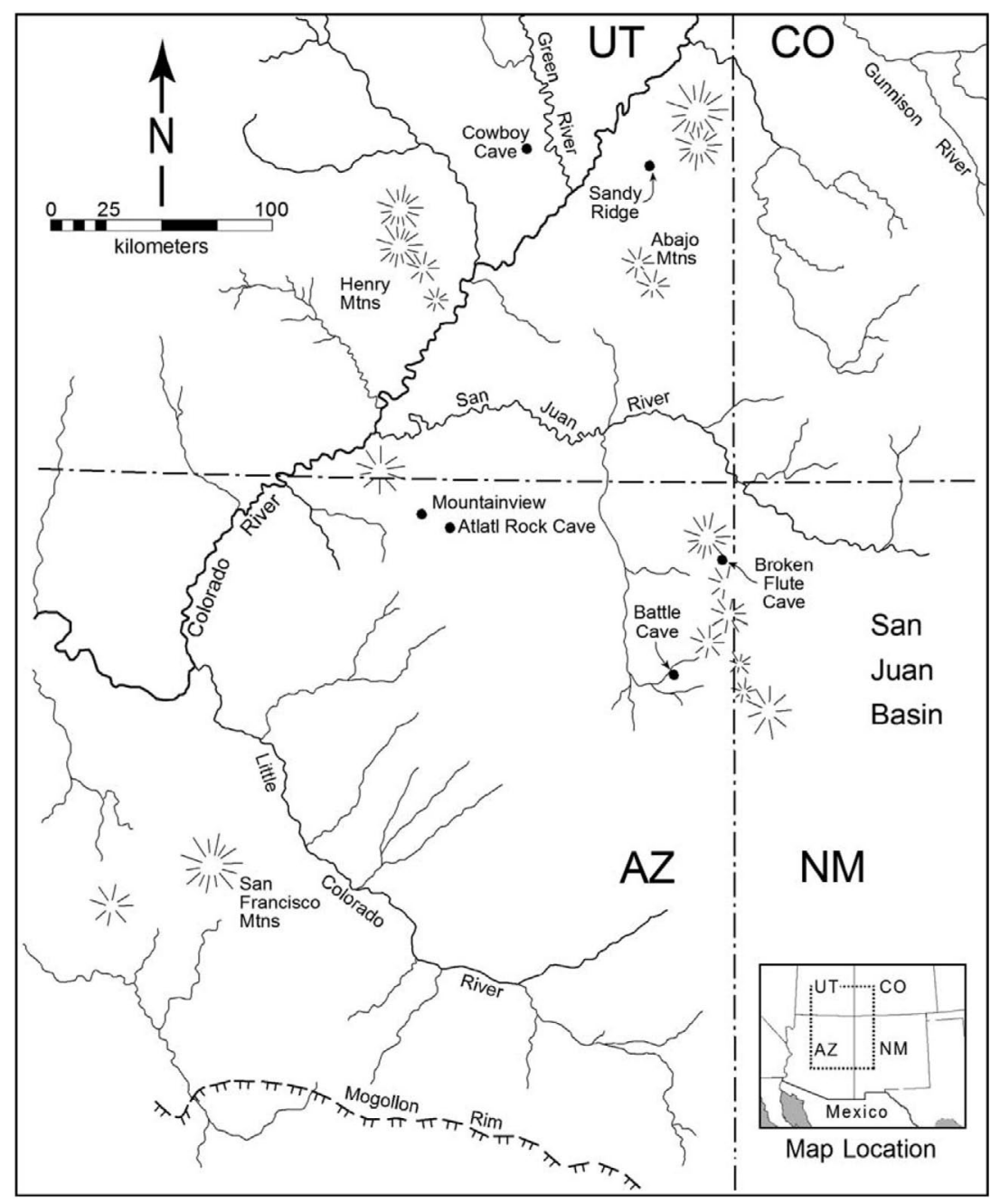

Figure 1. Map of the Four Corners region of the North American Southwest showing the locations of sites discussed in this article.

Despite the reliance on maize, Basketmaker II populations seem to have maintained considerable residential mobility; certainly the degree of sedentism increased in the centuries after $\mathrm{AD} 400$. It also seems true that the Neolithic demographic transition did not occur until after the addition of ceramics, bean cultivation, and use of improved maize varieties. ${ }^{16,18}$ Basketmaker II settlements were primarily small in scale, housing residential groups comprising extended or larger nuclear families. According to the original formulation, the Basketmaker III period saw the addition of two new technologies with important economic consequences: pottery and the bow and arrow. Significant, too, was the addition of domesticated beans and turkey husbandry if not outright domestication.

The key interval during the long Basketmaker era was the Basketmaker II to III transition, or roughly AD 400525. As the senior author noted more than a decade ago, ${ }^{19}$ key aspects of the ancient Pueblo way of life were embraced during this period, establishing the primary pattern followed for more than a millennium of subsequent development. Important aspects of this adaptation included a commitment to maize agriculture, cultivation of beans, use of ceramics, ${ }^{20}$ construction and use of large, deep pithouses, and a commitment to a much more sedentary way of life.

\section{Earliest Evidence of Bow Use in the Southwest}

Because of A.V. Kidder's original Pecos classification and division between Basketmaker II and III, most archeologists have assumed that bow technology was not part of the Basketmaker II adaptation. In fact, most continue to list the bow as a differentiating trait for the succeeding Basketmaker III period. However, there is evidence across the Southwest of bow use before AD 500 and perhaps as early as AD 100.

Kidder and other archeologists of his time certainly had good reason to believe that bow and arrow technology was absent during Basketmaker II but present during Basketmaker III. They had the good fortune of recovering the perishable components: the actual atlatls, darts, bows, and arrows. In all cases where they excavated in preceramic contexts, bow technology was absent but atlatl technology was present. In contrast, from ceramic contexts, Kidder and his colleagues recovered bow technology and, in the earliest of these, such as Broken Flute Cave of the Prayer Rock district in northeast Arizona, ${ }^{21}$ 


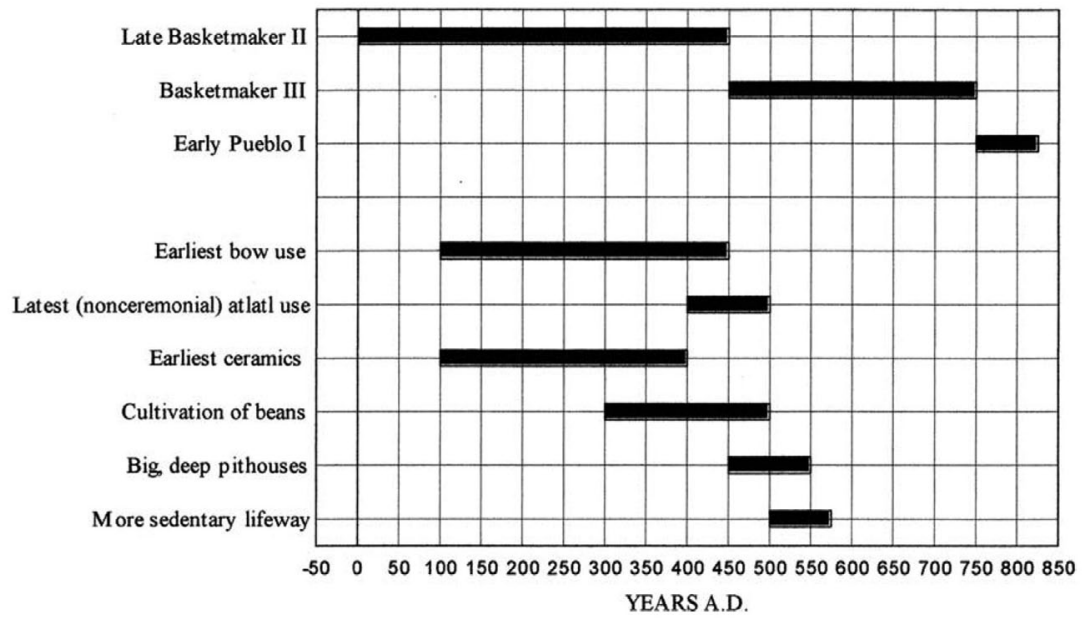

Figure 2. Chronological bar graph showing ancient Pueblo periods of interest and timing of critical events, including earliest bow use.

the last traces of atlatl technology (Fig. 2).

With the advent of AMS dating, we now know that many of the Basketmaker II contexts excavated by Kidder and his contemporaries were relatively early, often before the $\mathrm{BC} / \mathrm{AD}$ boundary. As a result of largeand small-scale contract archeology projects and research conducted with old collections over the last 30 years, considerably more is known about the temporal pattern of these technologies. The current evidence suggests that introduction of the bow and arrow had a complicated temporal and spatial pattern. In a general sense, the old framework is correct: By about AD 500, the bow and arrow was in general use and was the preferred projectile weapon for hunting or war. But before its ubiquitous use, bow technology made a spotty appearance in the northern Southwest, perhaps as early as AD 100. It also seems clear that the earliest use of this technology occurred in more northerly areas around the periphery of the Four Corners region.

Direct radiocarbon dates on atlatls, along with associated dates for dart points from secure stratigraphic contexts, confirm that atlatls have great antiquity in the Southwest and likely arrived with the initial migrants from northeast Asia or elsewhere (Paleoindian atlatls are reported by Hemmings ${ }^{22}$ and Whittaker ${ }^{23}$ ). Continued use of the atlatl up through the introduction of the bow and pottery is also verified by direct dating or stratigraphic associations with reliable dates. For example, an atlatl from Antelope Cave on the Arizona Strip has a direct date of $1850660 \mathrm{BP}$ (Beta-8394 ${ }^{24}$ ), which is late Basketmaker II (cal. AD 20-340, 2 sigma).

As with atlatl technology, archeologists have recovered the perishable and nonperishable components of bow technology from numerous sites throughout the Southwest: arrows, foreshafts, bows, bow strings, and arrow points. Unfortunately, direct radiocarbon dates on arrows or bows are exceedingly rare and the timing for the introduction of this technology is generally based on ceramic associations and tree-ring dates. Almost invariably, the remains of bow technology are recovered from depositional layers or features that also contained ceramics.
When these layers or features also yield datable tree-ring samples, this more than compensates for the lack of direct dating on bow or arrow remains, since the chronological resolution of dendrochronology allows precise dating for the emergence of a given technology, provided the contextual associations are accurately recorded. For example, when Earl Morris excavated sites in the Prayer Rock District of northeast Arizona, he uncovered bow and arrow fragments from pithouses that were tree-ring dated to AD 470-520 (early Basketmaker III). ${ }^{21,25}$

Differentiating arrow from dart points when the organic components, such as shafts, are missing, as they almost always are at open sites, is often problematic. Point size is a critical variable, with dart tips generally being much larger than arrow tips. These are often best summarized by size differences in the hafted elements (stems), on account of the reduced shaft diameter of arrows (or arrow foreshafts) when compared to darts (or dart foreshafts). Statistical verification comes from Shott's ${ }^{26}$ expansion of Thomas's ${ }^{5}$ study of hafted dart and arrow points, which demonstrates significant differences in summary metric data between dart and arrow points in virtually all measures. Shott's threshold value for distinguishing between dart and arrow points is a shoulder width of $20 \mathrm{~mm}$. Other researchers have emphasized neck width, ${ }^{27,28}$ with arrow points measuring $6 \mathrm{~mm}$ or less.

Given the limited sample of hafted projectiles, especially dart points, it is possible that some of the variability within certain regions has not been adequately characterized, with darts points that are within the threshold values for arrow points or vice versa. As a result, points of intermediate size might be wrongly classified, resulting in the inference that bow technology was present far earlier than it actually was. This seems to be the case in the southern Southwest with Cienega points, which Silva $^{29}$ subdivided into four subtypes, two of which she thought functioned exclusively as arrow tips, based on Shott's metrics; two-thirds of another subtype, she also classified as arrow points. This was taken as evidence that bow technology may have been in use as early 


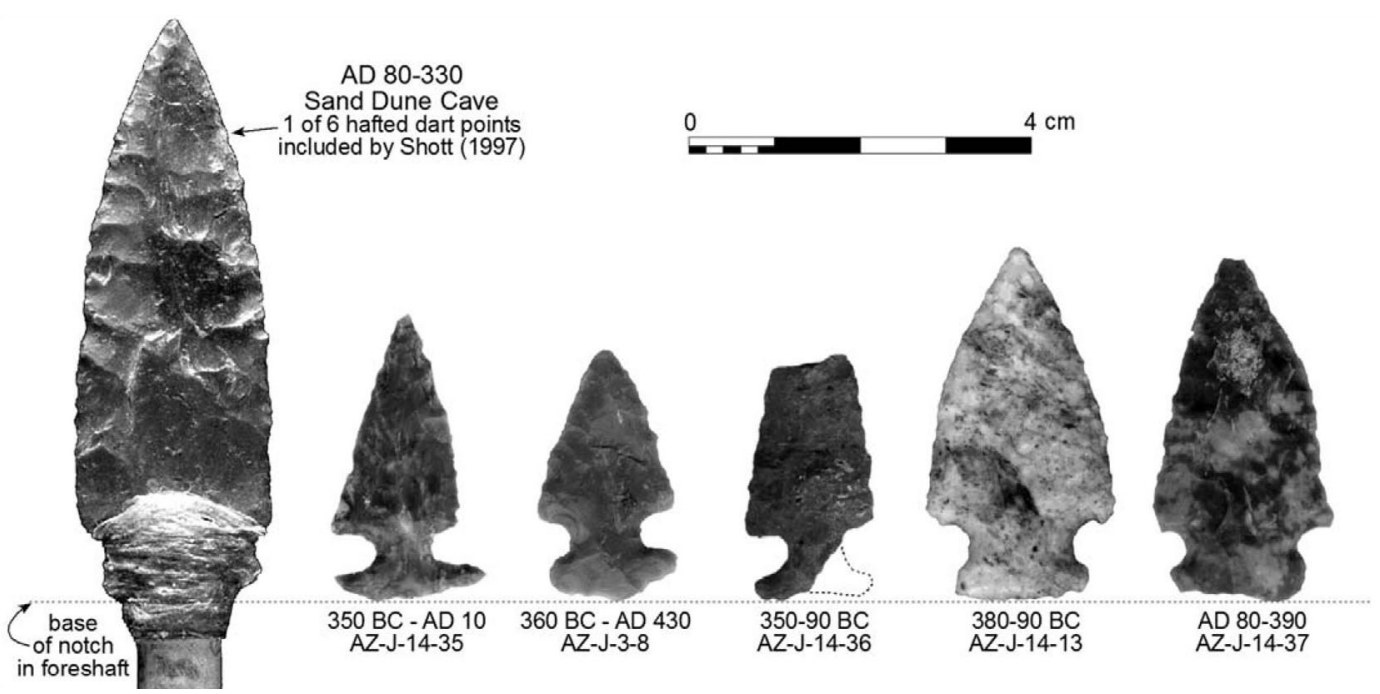

Figure 3. Contrast in size between a hafted Basketmaker II dart point in primary form that occurred within a cached hunter's bag and Basketmaker II dart points found at open sites of the same area; these dart points have been resharpened or rejuvenated after breaking. All sites occur on the Rainbow Plateau, SE Utah (see Geib8). as $800 \mathrm{BC}$ (beginning of the Cienega Phase) in southeast Arizona. However, the classificatory criteria developed by Shott might not adequately cover the range of variability in the size of dart or arrow points. In other words, Cienega points might be smaller than the hafted dart points that Shott used to generate his classificatory functions. Since his sample did not include any hafted specimens from southern Arizona, it is possible that dart points in this area were simply reduced in size and had a change in morphology (San Pedro to Cienega), leading up to the start of the Common Era. Certainly, projectile point size changed rather drastically by the Tortolita Phase (AD 450-600) ${ }^{30}$ when there is little doubt that the bow and arrow was in use. The same pattern occurs elsewhere in the Southwest and Great Basin: At some juncture, there is such miniaturization of point size that statistical classification procedures are hardly called for to decide whether an item tipped an arrow or a dart.

With regard to the specimens used by Shott ${ }^{26}$ it is worth noting that the Basketmaker II specimens, which included those from a hunter's bag at Sand Dune Cave, are large projectile points in primary form, most not exhibiting obvious traces of use, resharpening, or rejuvenation. This might be expected for items cached away for future use. These hafted pristine or nearly pristine points are not representative of the size range of Basketmaker II points, which are often found at habitations. These points appear to be reduced in size from use, resharpening, breakage, and refurbishment. Figure 3 illustrates this issue using one of the six hafted dart point foreshafts that came from the Sand Dune Cave hunter's bag (cache 1$)^{31}$ along with other projectile points excavated from open Basketmaker II sites of the area. ${ }^{8}$ These points appear to have been resharpened and perhaps reworked after breaking. The shoulder width for three of these points is less than $20 \mathrm{~mm}$, and thus arrow-sized according to Shott's criteria, yet such an assignment would doubtless be an error. Certainly we would never argue for bow use at any of these sites based on such evidence.
The important issue is that if Shott had access to darts points that reflected the full spectrum of their use-life rather than mainly the start, then the gray area between dart and arrow points would be much larger and assignment to one technology or another more nebulous and speculative.

Lyman and others ${ }^{7}$ suggest that there is a general evolutionary process surrounding the introduction of the bow and arrow and, perhaps, the introduction of new technology generally. The process is one of greater diversity early that becomes winnowed out through time as less-efficient variants stop being made. The initial diversity of arrow points is mainly attributable to experimentation with this new technology until suitable point tips were worked out. This early diversity is increased by the overlap of the two weapon systems, but the diversity is perhaps exaggerated because of the inability of archeologists to distinguish between dart and arrow points.

Unless one wants to make the rather tenuous argument for independent invention of this rather complicated projectile system, bow use in southern Arizona by 800 BC would be substantially earlier than elsewhere in the Southwest or indeed the Great Basin, Intermountain region, or the Great Plains, areas the technology presumably would have spread through in order to arrive in the Tucson area. So, until bow or arrow portions from the southern deserts of the Southwest are directly dated to earlier than about $400 \mathrm{AD}$ or until Cienega points are found hafted to certain arrows, then we side with those who consider Cienega points to be dart tips. ${ }^{32,33}$ Roth and her colleagues'30 recent review of evidence for the appearance of bow technology in the Mogollon region also places it at around AD 500, essentially the same time as in the southern deserts.

On the Colorado Plateau, the timing of bow and arrow introduction depends on where one looks. For much of the area south of the Colorado River in Arizona and New Mexico, the technology appears to date to roughly the same as for the Mogollon area and southern Arizona, to 
Figure 4. Contrast in size between arrow points and dart points at two largely contemporaneous sites on the Rainbow Plateau, SE Utah (see Geib8).
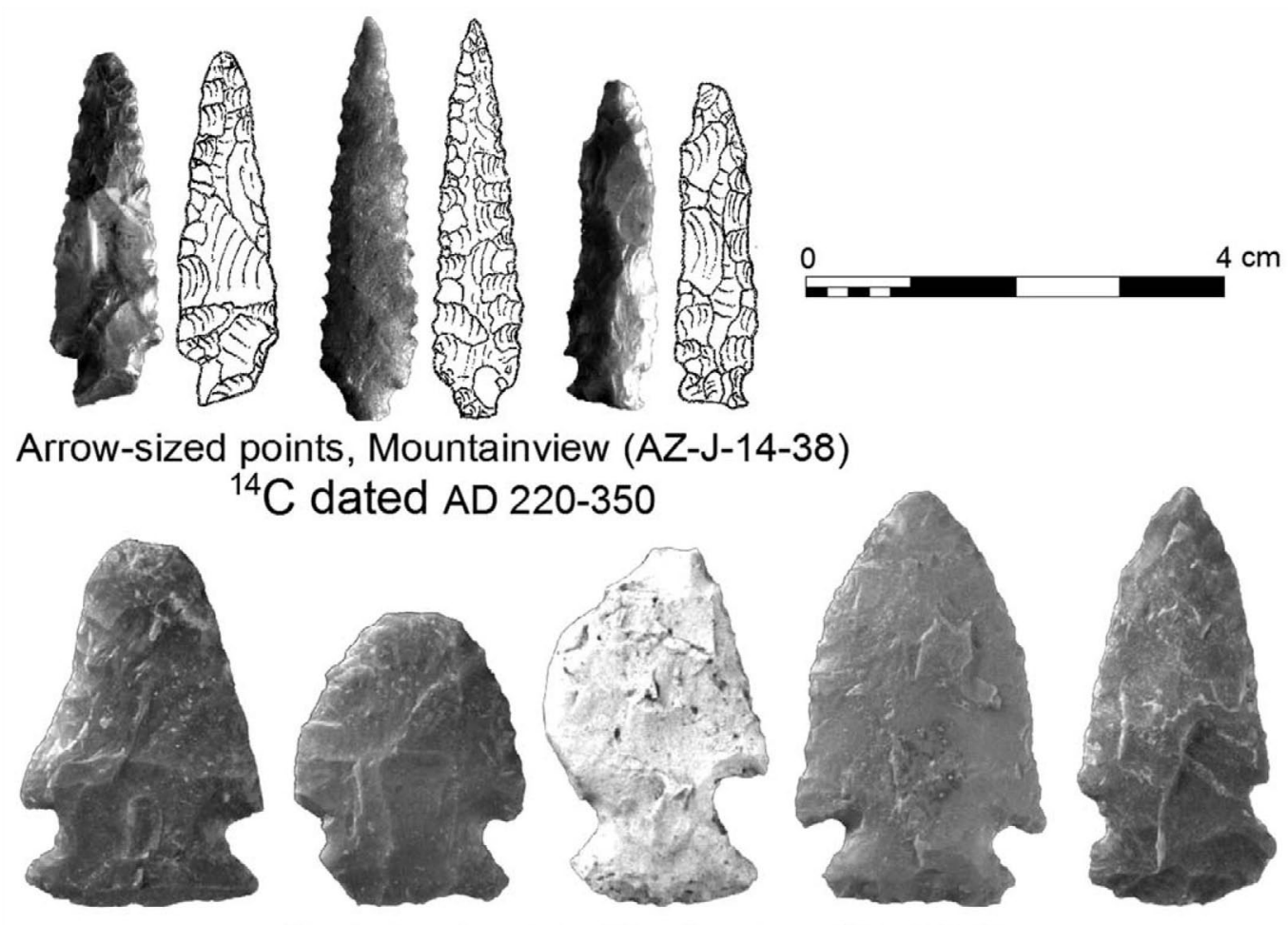

\section{Dart-sized points, Sin Sombra (AZ-J-3-6) \\ ${ }^{14} \mathrm{C}$ dated $A D 120-330$}

around AD 500. On the northern Colorado Plateau of Utah and Colorado there is good evidence of bow use several centuries before this (see recent review in $\mathrm{Geib}^{8}$ ). The evidence not only includes obvious arrow points - those of such a small size that no one would doubt an arrow tip assignment (Fig. 4) - but also arrow and bow portions such as those from Unit V at Cowboy Cave. ${ }^{34}$

Geib and Spurr ${ }^{35}$ suggest that the bow was in use on portions of Rainbow Plateau near the Arizona-Utah border by the $\mathrm{AD} 300$ s and perhaps as early as $\mathrm{AD} 220 .{ }^{8}$ This is based on the average of six contemporaneous radiocarbon assays on maize from a small habitation (Mountainview) that produced unmistakable arrow points of such a small size that an arrow tip assignment is beyond doubt, along with a full sequence of manufacturing failures from their production. ${ }^{8}$ Also present at the Mountainview site was early brown pottery. Further north at a site in Glen Canyon, Utah, there is evidence of bow use potentially as early as AD 100, ${ }^{36}$ although the dating could benefit from refinement. At the Sandy Ridge site near Moab, Utah, arrow points were recovered from a pithouse that is moderately well dated to the interval of roughly 200-300 AD. 37 This is almost identical to the Mountainview finding but, at Sandy Ridge, there was no evidence of pottery use.

The evidence of bow use by around AD 200-300 on the Rainbow Plateau, in portions of Glen Canyon and near Moab, does not mean that all groups occupying portions of the Four Corners area at this time used the bow and arrow. Indeed, even on the Rainbow Plateau, there are sites dated to the AD 200-300 interval that lack any evidence of bow use, but that do contain dart points. Also, there are some areas of dense late Basketmaker II occupation (ca. AD 1-400) in both southeast Utah and northeast Arizona that lack any evidence of bow and arrow technology, areas that have been well investigated by both survey and excavation. The best examples are Cedar Mesa and northern Black Mesa (see Smiley ${ }^{38}$ ). In other words, the evidence of bow use during Basketmaker II seems very patchy and limited to a time late in the period, after the beginning of the Common Era.

\section{Bow Use in Warfare}

Much has been written on the role of the bow in ancient warfare. Here we offer a brief discussion of the role of the bow in ancient Southwestern warfare. The archeological literature on Southwestern warfare has exploded over the last 15 years. ${ }^{39-48}$ The emerging consensus is that warfare was an important component of culture change in the past, in contrast with the classic monolithic, peaceful, Apollonian view of Pueblo people. ${ }^{49}$ The Southwest record makes it clear that significant intergroup conflict predated the advent of bow technology. There are two massacre assemblages known for the Basketmaker II period: Wetherill's Cave 7 in southeast $\mathrm{Utah}^{50}$ and Battle Cave in northeast Arizona. ${ }^{51}$ Both of these assemblages predate the use of bow and arrow technology. There also is plenty of compelling evidence for intergroup conflict 
during Basketmaker II, such as full head scalps, ${ }^{22,53}$ rock art depictions of atlatl fights, ${ }^{51}$ single individuals with perimortem damage (for example, the Red Canyon skull reported by Turner and Turner ${ }^{51}$ ), and even defensive sites, such as the "Rock Island site" Cedar Mesa, Utah. ${ }^{54}$ If anything, there appears to have been a decline in intergroup conflict during the first few centuries after the introduction of the bow and arrow. There are no known examples of massacre assemblages during Basketmaker III nor are single skeletons reported that have perimortem damage that could be attributed to intergroup conflict. Not until the Pueblo I period, a few hundred years after the introduction of the bow and arrow, are there unmistakable signs of warfare. The best example of this is Sacred Ridge in southeast Colorado, where at least 35 individuals were dispatched at one time. 55

\section{Why the Switch to Bow-Arrow Technology?}

An extensive literature exists on the nature of the transition from atlatldart to bow-arrow technology, as mentioned earlier. The discussion here is not intended to be exhaustive, but rather to frame the arguments. Emerging from the new archeology of the 1960 s and a generalsystems theory perspective, Glassow ${ }^{56}$ advocated the interconnectivity of multiple Basketmaker technological changes, including the move to bowarrow use: Covarying with the changes in storage and conversion facilities is a shift from one type of hunting weapon to another: the atlatl and dart to the bow and arrow. He saw this shift as probably directly related to the restructuring of human activities from Early to Late Basketmaker times. The bow and arrow would have improved efficiency by providing the advantages of ambush, expanding the hunt to more thickly wooded lands, and perhaps by increasing the variety of smaller animals that could be effectively hunted.

Raymond $57: 171$ concluded that "it is generally considered. . that the bow and arrow replaced the atlatl because the bow is a superior weapon. ... [But] people did not embrace bow and arrow technology because it packs a bigger punch than the atlatl, since it does not.. . . [Rather] the chief advantage of the bow and arrow lies in the ease and swiftness of the movements involved when shooting the projectile."

LeBlanc ${ }^{4: 99-100}$ noted that "an arrow shot from a selfbow flies more than 50 percent faster than a dart thrown from an atlatl. ... These measurements were taken with ethnographically collected weapons at a time when bow technology was declining. ... Therefore, it can be surmised that, in the Southwest, the self-bow was a potentially more dangerous weapon than the atlatl." In contrast to LeBlanc's view, Shott ${ }^{6}$ concluded that ethnographic data do not suggest that the bow was more efficient than atlatl-driven darts. But, he noted the lack of ethnographic data on the issue.

In our view, there are at least three key benefits of the bow over the atlatl and dart. One of these concerns the learning curve for effective use, which is steep for the atlatl and dart but comparatively shallow for the bow and arrow. Geib has observed this in demonstrations of prehistoric technology to school children. Most first-timeusers of the atlatl and dart have difficulty deploying the implement, sometimes even after repeated instruction, whereas most first-time-users of a bow readily achieve proficiency and can hit targets with a fair degree of accuracy after just a few shots.

Two somewhat related key benefits of bows over atlatls concern bodily movement and space, with comparatively little of both required for effective use of the bow but the opposite for the atlatl. One can shoot a bow while crouched in cover or within the confines of a small room and send the arrow flying with potentially deadly force through a slit the size of a peep hole. This could never be done with an atlatl and dart, which require a minimum of 1-2 meters of open space around the user and a step or two forward for optimal force delivery. Archeologists who have tried hunting with atlatls immediately learn that it is the necessary bodily motion in use that reduces the effectiveness of the atlatl in hunting situations except against a milling herd, since it startles the game animal into flight or evasive action. ${ }^{58}$ With bow technology, this aspect has minimal significance and hunters often note that it is string noise on release rather than any motion that might startle game.

Discussing osteological evidence from across North America, Lambert observed that after AD 500, there was a substantial increase in the frequency of reported injuries attributable to violence. ${ }^{59}$ Is this finding related to the widespread adoption of bow technology after 500? It certainly seems likely. Lambert goes on to suggest that once one group in an area adopts a certain advantageous technology, other groups often feel pressured to do so as well in order to maintain levels of security. In other words, the introduction of a militarily beneficial technology like the bow can lead to a small-scale arms races and further advances in technology.

Early bow use does not seem to be correlated with any particular change in environment or inferred availability of game animals. Moreover, the bow is not necessarily a superior killing implement to the atlatl since that depends on various factors, including the game animals, the environment (open grasslands versus dense woods), and the social context of hunting (group versus individual, men alone versus women and children). So it strains credibility to suggest that advantages in hunting alone can explain the rather sudden replacement of one technology by another. Success in hunting with the bow and arrow by early adopters of the technology might have exerted some selective pressure for adjacent groups to follow suit, but we believe that a more significant point had to do with competitive intergroup relationships. In short, we suggest that the widespread adoption of the bow eventually conferred a significant military advantage on the initial adopting groups, either for defense or offense, 
and probably both. Subsequently, the competition from these groups either directly or indirectly caused others to respond by adopting the same technology.

\section{Warfare Versus Social Coercion Theory}

In the introduction and conclusion to this issue, Bingham and coworkers ${ }^{9,10}$ present two theories to explain the emergence of bow-arrow technology: warfare and social coercion. Evaluating the data from the ancient Pueblo world, we do not find direct support for the warfare theory. With the emergence of the bow in the AD 100-400 interval, we see no evidence of an increase in warfare or conflict during this period. One of the key tenets of warfare theory states that warfare will increase concurrently with adoption of bow technology; this is not supported by data from the Pueblo Southwest. In contrast, the data show a significant lag, with warfare/conflict on the rise by perhaps the late-6oos to late-70os. ${ }^{4}$ This finding supports social coercion theory, which invokes a lag time between the emergence of bow technology and local increases in warfare and social conflict. Furthermore, social coercion theory proposes that increased warfare will follow other symptoms of increasing complexity, which we do see in ancient Southwest. Finally, social coercion theory predicts that "local introduction of improved weaponry will be followed rapidly by increases in social scale and economic intensification." ${ }^{9}$ We do find support for this prediction in the archeological record of the Southwest. In summary, we do not find data to support warfare theory but do see support for social coercion theory.

\section{Conclusions}

We have evaluated the data for the emergence of bow and arrow technology in the ancient Pueblo Southwest. We reach several conclusions on the basis of our study:

1. Bow-arrow technology appeared in the ancient Southwest during the $\mathrm{AD} 100-400$ interval.

2. At about the same time, during the late Basketmaker II period, ancient Pueblo culture made the transition from mobile to a much more sedentary lifestyle.,

3. Bow technology improved the ability of southwestern and other North American groups to conduct warfare, but the emergence of the bow did not result in immediate warfare or conflict. Rather, we see a lag of several hundred before evidence of warfare in the record appears after AD 650 or 700.

4. Bow and arrow technology was part of a suite of traits that increased social complexity among ancient Pueblo groups.

5. Of the two theories, warfare or social coercion, we find greater support for social coercion theory as we assess the archeological record of the ancient Pueblo Southwest.

\section{References}

1 Bettinger RL, Eerkens W. 1997. Evolutionary implications of metrical variation in Great Basin projectile points. In: Barton $\mathrm{CM}$, Clark GA, editors. Rediscovering Darwin: evolutionary theory and archaeological explanation. Archaeological Papers of the American Anthropological Association, Arlington, Virginia. $\mathrm{p}$ 177-191.

2 Bleed P. 1986. The optimal design of hunting weapons: maintainability and reliability. Am Antiquity 51:737-747. 3 Blitz JH. 1988. Adoption of the bow in prehistoric North America. N Am Archaeol 9:123-145.

4 Browne, J. 1938. Antiquity of the bow. Am Antiquity 3:358-359.

5 Thomas DH. 1978. Arrowheads and atlatl darts: how the stones got the shaft. Am Antiquity 43:461-472.

6 Shott MJ. 1993. Spears, darts, and arrow: Late Woodland hunting techniques in the Upper Ohio Valley. Am Antiquity 58:425-443.

7 Lyman RL, Van Pool T, O'Brien MJ. 2008. Variation in North American dart points and arrow points when one or both are present. J Archaeol Sci 35:2805-2812.

8 Geib PR. 2011. Foragers and farmers of the Northern Kayenta region: excavations along the Navajo Mountain road. Salt Lake City: University of Utah Press.

9 Bingham PM, Souza J, Blitz JH. 2013. Social complexity and the bow in the prehistoric North American record. Evol Anthropol 22:81-88.

10 Bingham PM, Souza J. 2013. Theory testing in prehistoric North America: fruits of one of the world's great archeological natural laboratories. Evol Anthropol 22:145-153.

11 Kidder AV. 1927. Southwestern archaeological conference. Science 66:489-491.

12 Matson RG. 1991. Origins of southwest agriculture. Tucson: University of Arizona Press.

13 Huber, EK. 2005. Early maize at the Old Corn Site (LA 137258). In: Huber EK, Van West CR, editors. Fence Lake Project: archaeological data recovery in the New Mexico Transportation Corridor and First Five Year Permit Area, Fence Lake Coal Mine Project, Catron County, New Mexico, vol. 4: synthetic studies. SRI Technical Series 84. Tucson; Statistical Research p. 36.1-36.14.

14 Chisholm B, Matson RG. 1994. Carbon and nitrogen isotopic evidence on Basketmaker II diet at Cedar Mesa, Utah. Kiva 6o:239-256.

15 Coltrain JB, Janetski JC, Carlyle SW. 2007. The stable- and radioisotope chemistry of western Basketmaker burials: implications for early Puebloan diet and origins. Am Antiquity 72:301-321.

16 Reed PF. 200o. Early Anasazi agriculture during the Basketmaker II Period along the Northern Chuska Slope, New Mexico and Arizona. Presented at the 65th annual meeting of the Society for American Archaeology, April 200o, Philadelphia.

17 Matson RG, Chisholm B. 1991. Basketmaker II subsistence: carbon isotopes and other dietary indicators from Cedar Mesa, Utah. Am Antiquity 56:444-459.

18 Kohler TA, Glaude MP, Bocquet-Appel J-P, et al. 2008. The Neolithic demographic transition in the U.S. Southwest. Am Antiquity 73:645-669.

19 Reed PF. 200o. Fundamental issues in Basketmaker archaeology. In: Reed PF, editor. Foundations of Anasazi culture: the Basketmaker-Pueblo transition. Salt Lake City: University of Utah Press.

20 Reed LS, Wilson CD, Hays-Gilpin KA. 2000. From brown to gray: the origins of ceramic technology in the northern Southwest. In: Reed PF, editor. Foundations of Anasazi culture: the Basketmaker-Pueblo transition. Salt Lake City: University of Utah Press.

21 Morris EA. 1980. Basketmaker Caves in the Prayer Rock District, northeastern Arizona. University of Arizona Anthropological Papers No. 35. Tucson: University of Arizona Press. 
22 Hemmings CA. 2004. The organic Clovis: a single continentwide cultural adaptation. Unpublished Ph.D. dissertation, University of Florida.

23 Whittaker JC. 2007. Clovis atlatls? Hemmings' evidence from Florida rivers. Atlatl 20:14.

24 Janetski JC, Hall MJ. 1983. An archaeological and geological assessment of Antelope Cave (NA5507), Mohave County, northeastern Arizona. Technical Series No. 83-73. Provo: Brigham Young University, Department of Anthropology.

25 Reed PF, Wilcox S. 2000. Distinctive and intensive: The Basketmaker III to Early Pueblo I occupation of Cove-Redrock Valley, northeastern Arizona. In Reed PF, editor. Foundations of Anasazi culture: the Basketmaker-Pueblo transition. Salt Lake City: University of Utah Press.

26 Shott MJ. 1997. Stones and shafts redux: the metric discrimination of chipped-stone dart and arrow points. Am Antiquity 62:86-101.

27 Corliss DW. 1972. Neck width of projectile points: an index of culture continuity and change. Occasional Paper No. 29. Pocatello: Idaho State University Museum.

28 Fawcett WB, Kornfeld M. 1980. Projectile point neck-width variability and chronology on the Plains. Wyoming Contrib Archaeol 2:66-79.

29 Silva RJ. 1999. Cienega points and Archaic period chronology in the southern Southwest. Kiva 64:339-367.

30 Roth BJ, Toney E, Lorentzen L. 2011. The advent of bow and arrow technology in the Mimbres Mogollon region. Kiva 77:87-109.

31 Geib PR. 2004. AMS dating of a Basketmaker II hunter's bag (cache 1) from Sand Dune Cave, Utah. Kiva 69:271-282.

32 Huckell BB. 1995. Of marshes and maize: preceramic agricultural settlements in the Cienega Valley, southeastern Arizona. Anthropol Papers University of Arizona 59. Tucson: University of Arizona Press.

33 Roth BJ, Huckell BB. 1992. Cortaro points and the archaic of Southern Arizona. Kiva 57:353-370.

34 Janetski JC. 1980. Wood and reed artifacts. In: Jennings JD, editor. Cowboy cave. Anthropological Papers No. 104. Salt Lake City: University of Utah Press. p 75-95.

35 Geib PR, Spurr K. 2000. The Basketmaker II-III transition on the Rainbow Plateau. In: Reed PF, editor. Foundations of Anasazi culture: the Basketmaker-Pueblo transition. Salt Lake City: University of Utah Press.

36 Geib PR, Bungart P. 1989. Implications of early bow use in Glen Canyon. Utah Archaeol 2:32-47.

37 Richens LD, Talbot K. 1989. Sandy Ridge: an aceramic habitation site in Southeastern Utah. Utah Archaeol 1:77-88.

38 Smiley FE. 2002. The first Black Mesa farmers: The White Dog and Lolomai Phases. In: Powell S, Smiley FE, editors. Prehistoric culture change on the Colorado Plateau: ten thousand years on Black Mesa. Tucson: University of Arizona Press. p 37-65.

39 Billman BR, Lambert PM, Leonard B. 2000. Cannibalism, warfare, and drought in the Mesa Verde region during the twelfth century CE. Am Antiquity 65:145-178.

40 Upham S, Reed PF. 1989. Inferring the structure of Anasazi warfare. In Tkaczuk DC, Vivian BC, editors. Cultures in conflict. Proceedings of the 12th Annual Chacmool Conference, University of Calgary, Alberta, Canada. Archaeological Association of the University of Calgary, Alberta. p 153-162.

41 Haas J, Creamer W. 1996. The role of warfare in the Pueblo III Period. In: Adler M, editor. The prehistoric Pueblo world CE 11501350. Tucson: University of Arizona Press. p 203-213.
42 Kuckelman KA. 2002. Thirteenth-century warfare in the Central Mesa Verde region. In: Varien,MD, Wilshusen RH, editors. Seeking the center place: archaeology and ancient communities in the Mesa Verde region.,Salt Lake City: University of Utah Press. p 233-253.

43 Kuckelman KA, Lightfoot RR, Martin DL. 2002. The bioarchaeology and taphonomy of violence at Castle Rock and Sand Canyon pueblos, southwestern Colorado. Am Antiquity 67:486-513.

44 LeBlanc S. 1999. Prehistoric warfare in the American Southwest. Salt Lake City: University of Utah Press.

45 Rice GE, LeBlanc S. 2001. Deadly landscapes: case studies in prehistoric Southwestern warfare. Salt Lake City: University of Utah Press.

46 Lightfoot RR, Kuckelman K. 2001. A case of warfare in the Mesa Verde region. In Rice GE, LeBlanc SA, editors. Deadly landscapes: case studies in prehistoric Southwestern warfare. Salt Lake City: University of Utah Press. p 51-64.

47 Martin DL. 1997. Violence against women in the La Plata River Valley (CE 1000-1300). In: Martin DL, Frayer DW, editors. In troubled times: evidence for violence and warfare in the past. Overseas Publishers Association, Amsterdam. p. 45-76.

48 Wilcox DR, Haas J. 1994. The scream of the butterfly: competition and conflict in the prehistoric Southwest. In: Gumerman GJ, editor. Themes in Southwest prehistory. Santa Fe: School of American Research Press. p 211-238.

49 Benedict RF. 1934. Patterns of culture. New York: Houghton Mifflin.

50 Hurst W, Turner CJ. 1993. Rediscovering the "great discovery": Wetherill's First Cave 7 and its record of Basketmaker violence. In: Atkins V, editor. Anasazi Basketmaker: Papers of the 1990 Wetherill-Grand Gulch Symposium. Cultural Resource Series 24, Bureau of Land Management, Salt Lake City, UT. p 143-191.

51 Turner C, Turner J. 1999. Man corn. Salt Lake City: University of Utah Press.

52 Guernsey SL, Kidder AV. 1921. Basket Maker caves of northeastern Arizona. Papers of the Peabody Museum of American Archaeology and Ethnology, Vol. 8, No. 2. Cambridge: Harvard University.

53 Howard J, Janetski J. 1992. Human scalps from eastern Utah. Utah Archaeol 5:125-132.

54 Matson RG. 1994. Anomalous Basketmaker II sites on Cedar Mesa: not so anomalous after all. Kiva 60:219-238.

55 Potter JM, Chuipka J. 2010. Perimortem mutilation of human remains in an early village in the American Southwest: a case for ethnic violence. J Anthropol Archaeol 29:507- 523.

56 Glassow M. 1972. Changes in the adaptations of Southwestern Basketmakers: a systems perspective. In: Leone M, editor. Contemporary archaeology. Carbondale: Southern Illinois University Press. p 289-302.

57 Raymond A. 1986. Experiments in the function and performance of the weighted atlatl. World Archaeol 18:153-177.

58 Graham M. 2007. Observations with primitive hunting tools. Bull Primitive Technol 33:73-78.

59 Lambert PM. 2007. Osteological evidence for indigenous warfare in North America. In: Chacon RJ, Mendoza RG, editors. North American indigenous warfare and ritual violence. Tucson: University of Arizona Press. p 202-221. 